Pediat. Res. 5: 53-58 (1971)

Maternal-fetal interaction

newborns

thỵrotropic hormone thyroxine

thyroxine-binding

globulin

\title{
Thyroid Function Studied in Paired Maternal-Cord Sera and Sequential Observations of Thyrotropic Hormone Release during the First 72 Hours of Life
}

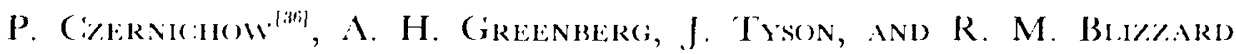

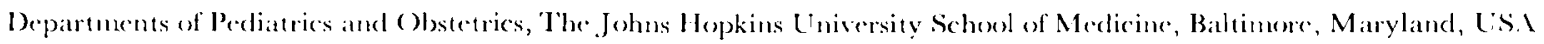

\section{Extrait}

Pituitary thyrotropic hormone (TSH) was measured in seven normal newborns followed during the first $72 \mathrm{hr}$ of life. These infants demonstrated an acute unsustained release of TSH in the early minutes of postnatal life. Peak levels occurred between 15 and 30 min after birth, increasing from cord levels ranging from $3.210 .7 \mu$ units $\mathrm{ml}$ to a maximal elevation in sera of $25-163 \mu$ units, $m$. 'This rise was followed by a steep decline in serum levels at an initial rate comparable to that reported for the half-life of the hormone. A slower rate of decay was noted after $120 \mathrm{~min}$.

The TSH levels in 20 normal paired maternal and cord samples indicated that cord levels were consistently higher $(t=5.9(), P<0.00)$ ). Maternal levels were comparable to those found in nompregnant adult females; however, cord levels of 'TSH were higher than that expected for normal children. Specificity of the TSH assay would indicate that immunoreactive TSH in maternal and cord sera was of pituitary origin.

Maternal thyroxine levels were significantly greater than those of cord sera $(t=$ $3.31, P<0 .(01)$, reflecting similarly higher levels of thyroxine-binding globulin ('TBG) in maternal specimens $(t=7.31, P<0.001)$. No significant differences $(l=1.11$, $P>0.2)$ existed when levels of free thyroxine $\left(\mathrm{F}^{\prime} \mathrm{I}_{4}\right)$ in maternal and cord sera were compared.

\section{Spreculation}

The relatively high levels of TSH in cord serum in the presence of normal or high normal free thyroxine concentrations would suggest that the hypothalamic-pituitary responsiveness to thyroxine in the fetus is altered. Free thyroxine concentrations that maintain 'TSH in the euthyroid range in normal children are apparently unable to do so in the fetus. Any other hypothesis for this observation must necessarily postulate a persistent stimulus to TSH secretion in utero. One such postulated stimulus could be a relatively low serum concentration of free triiodothyronine $\left({ }^{\prime} \Gamma_{3}\right)$ in the fetus.

\section{Introduction}

Laboratory findings suggestive of hyperthyroidism in the neonate were first described by Danowski ct al. [2] in 1951. Subsequently, many studies have examined different aspects of thyroid physiology in the first hours of life. Thyroid metabolism in the newborn, however, is still not totally understood. In this study we have assessed some of the more important variables 
of pituitary-thyroid function in an attempt to clarify the nature of this apparent hyperthyroid state.

\section{Materials and Methods}

Twenty paired maternal and cord sera samples were studied. Informed consents were obtained from all subjects in accord with the Helsinki Declaration. All the mothers were normal, healthy, pregnant women and delivered nomal infants by the vaginal route without complication. Epidural anesthesia was routinely used.

Seven of the 20 newborns were followed cluring the first 2 or 3 days of life. Blood was drawn at 15, 40, 60, and $120 \mathrm{~min}$, and at $6,2 \cdot 1,18$, and $72 \mathrm{hr}$ of life. Venipunctures were done to obtain maternal specimens, and the cord, 6-hr and 2-thr specimens from the infants. The other blood samples from infants were obtained by capillary bleeding. Cord and maternal sera were drawn simultaneously at the time of delivery.

The 'ISH assay was performed by a double antibody technique [21]. Highly purifed human thyrotropic hormone (HTSH) (2.5) $\mu_{\mathrm{s}}$ ) wals iodinated with $100 \mu \mathrm{Ci}$ ${ }_{125}$ I by the method of Greenwood, Hunter, and Cilover [12]. Serum samples were prepared in an incubation volume of $1.0 \mathrm{ml}$ composed of $100 \mu$ H HTSH antisera [30], 1:20,000: $100 \mathrm{ml}$ human chorionic gonadonopin (HCC) (20 IU); $100 \mu \mathrm{l} 0.1 \mathrm{~m} ; 100 \mathrm{ml}$ 12.5I-HISH (0.I $\mathrm{ng}$ ); $400 \mu \mathrm{l}$ serum; and $200 \mu \mathrm{l}$ phosphate-buffered saline with $0.1 \%$ bovine scrum albumin. Results are expressed as microunits per milliliter of Human Thyrotropin Research Standard A [31]. All standards contained $400 \mu$ bovine serum. Appropriate ansounts of bovine serum were added to samples so that each tube contained at least $400 \mu \mathrm{l}$ serum. 'Two microliters normat rablit serum were added to cach tube. After incubation for 6 (lays at $1^{\circ}$, sheep antirabbit gamma globulin antiserum, which was titrated for maximal precipitation, was added. Specimens were centrifuged and counted after incubation for $2.1 \mathrm{hr}$ at $4^{\circ}$. Simples were assayed in triplicate, and all serat were measured in the same assay. Several specimens and one serum sample

Table 1. Comparison of 'TSH levets'

\begin{tabular}{|c|c|c|}
\hline \multirow{2}{*}{ Sample } & \multicolumn{2}{|c|}{ TSII, $\mu$ units $/ \mathrm{ml}$} \\
\hline & lenous & (appillary \\
\hline 1 & 2.6 & 2.9 \\
\hline 2 & 2.3 & $2.6 i$ \\
\hline 3 & 1.6 & 2.1 \\
\hline 4 & 10.0 & 8.6 \\
\hline 5 & 5.3 & 5.5 \\
\hline
\end{tabular}

${ }^{1}$ Paired sera samples obtained from venous and capillary blowed. from a hypothyroid subject were assayed at different dilutions to demonstrate proportionality. Intraassay variability at $95 \%$ confidence limits for a single serum, which was measured 10 times in duplicate on the sensitive portion of the standard curve, was $4.7 \%$. All normal sera measured less than $7.0 \mu u n i t s / m l$. Forty percent of sera from normal adults and children was below the limits of sensitivity $(1.25 \mu u n i t s / \mathrm{ml})$. Paired TSH values from venous and capillary serum obtained simultaneously were comparable (Table 1).

Serum thyroxine concentrations were determined by the Murphy-Pattee method [32]. Results are expressed in micrograms thyroxine per $100 \mathrm{ml}$. All determinations were corrected for a recovery of $77 \%$. Coefficient of variation for intratassay variability at $95 \%$ conftdence limits was $8.0 \%$.

Thyroxine-biuling globulin (TBG) was assessed by reverse flow paper electrophoresis in glycine acetate buffer at pH 8.6 [15]. Fach sample was enriched with $<6 \mu \mathrm{g} / \mathrm{l}\left(00 \mathrm{ml}\right.$ tracer ${ }^{131} \mathrm{I}_{-} \mathrm{I}_{4}$. Cord sera were assayed for maximal binding capacity with 200 and $300 \mu \mathrm{g} / 100$ $\mathrm{ml}$ and maternal sera with 300 and $400 \mu \mathrm{g} / 100 \mathrm{ml}$ of added cold thyroxine, respectively. A current of 12.0 ma was applied for $18 \mathrm{hr}$, and the electrophoresis strips were dried and scamned for radioactivity in an automatic gas flow counter. The distribution of radioactivity was assessed by manual planimetry. The coefficient of variation for intra- and interassay variability at $95 \%$ confidence limits wats 11.2 and $16.7 \%$, respectively.

Free thyroxine was ansayed by the method of Sterling and Brenner [28]. Purity of the ${ }^{131}{ }^{12}-T_{4}$ [33] was determined by thin layer chromatography on cellulose plates with the use of a two-dimensional system [5]. Thyroxine accounted for $9.1 .6 \%$, iodicle for $3.0 \%$, triiodothyronine for $1.3 \%$, and diiodotyrosine for $1.1 \%$ of the radionctivity, respectively. The ${ }^{131} \mathrm{I}-\mathrm{I}_{4}$ was dialyzed against 8 liters of 0.15 i potassium phosphate buffer, pll 7.1. for 18 he prior to use in the assay [27]. All samples were assayed in duplicate in a single assay at a dilution of $1: 25$. The free thyroxine fraction $\left(\mathrm{FT}_{4} \mathrm{~F}\right)$ was corrected for the dilution, and the absolute free thyroxine concentration $\left(\mathrm{F}_{4}\right)$ was calculated as the product of the $\mathrm{FT}_{4} \mathrm{~F}$ and the serum thyroxine concentration. The coeflicient of variation for intraassay variability at $95 \%$ confidence limits was $5.7 \%$.

\section{Results}

An acute increase in TSH levels occurred within the first minutes of life in the seven newborns studied. Peak values occurred between 15 and $30 \mathrm{~min}$ and 
Table 11 . TSH, thyroxine, free thyroxine, and thyroxine-binding globulin concentration in 20 paired sanples of maternal and cord sera

\begin{tabular}{|c|c|c|c|c|c|c|c|c|c|c|}
\hline \multirow{2}{*}{ Samples } & \multicolumn{2}{|c|}{ TSH, $\mu$ units'ml } & \multicolumn{2}{|c|}{$\mathrm{T}_{1}, \mu \mathrm{g} / 100 \mathrm{ml}$} & \multicolumn{2}{|c|}{$\mathrm{TB}(\mathrm{g}, \mu \mathrm{g} / 100 \mathrm{ml}$} & \multicolumn{2}{|c|}{$\mathrm{FT}_{4} \mathrm{~F}, \times 10^{-2 / 100 \mathrm{ml}}$} & \multicolumn{2}{|c|}{$\mathrm{FT}_{4}, \mathrm{ng} / 100 \mathrm{ml}$} \\
\hline & Mitternal & cord & Maternal & Cord & Maternal & Cord & Maternal & cord & Maternal & Cord \\
\hline 1 & $<1.25$ & 3.2 & 15.9 & 15.9 & 44.6 & 28.3 & 1.90 & 2.10 & 3.02 & 3.34 \\
\hline 2 & $<1.25$ & 2.1 & 18.2 & 13.0 & 44.6 & 22.3 & 2.10 & 2.68 & 3.82 & 3.48 \\
\hline 3 & 2.3 & 6.8 & 17.1 & 10.7 & 32.1 & 21.7 & 1.85 & 2.99 & 3.16 & 3.20 \\
\hline 4 & $<1.25$ & 10.7 & 16.3 & 18.2 & 43.4 & 28.0 & 2.15 & 2.45 & 3.50 & 4.46 \\
\hline 5 & 1.35 & 8.7 & 15.0 & 19.5 & 41.8 & 24.5 & 2.43 & 2.09 & 3.65 .5 & 4.08 \\
\hline ij & $<1.25$ & 2.13 & 11.4 & 11.4 & 39.4 & 27.3 & 2.17 & 1.97 & 2.47 & 2.25 \\
\hline 7 & $<1.25$ & 4.4 & 17.7 & 18.7 & 39.8 & 32.7 & $\cdot-$ & $\cdots$ & --- & - \\
\hline 8 & 4.0 & +.11 & 15.6 & 16.3 & 52.5 & 26.7 & 2.14 & 2.26 & 3.34 & 3.68 \\
\hline 9 & 1.3 & 2.1 & 17.7 & 19.7 & .38 .2 & 16.1 & 2.38 & 2.70 & 4.21 & 5.332 \\
\hline 10 & 1.7 & 7.8 & 14.8 & 9.9 & 81.9 & 28.0 & 2.47 & 2.96 & 3.66 & 2.93 \\
\hline 11 & 2.0 & 3.1 & 12.4 & 7.8 & 61.5 &.- & 2.23 & 5.16 & 2.77 & 4.02 \\
\hline 12 & 5.1 & 7.2 & 13.5 & 11.8 & 67.1 & 3.3 .7 & 3.17 & 3.37 & 4.28 & 3.98 \\
\hline 13 & 1.8 & 8.2 & 10.4 & 8.2 & ti4.5 & 31.4 & 2.76 & 2.92 & 2.87 & 2.39 \\
\hline 14 & $<1.25$ & 2.5 & 10.9 & 9.1 & 44.8 & 27.5 & 2.09 & 3.27 & 2.78 & 2.98 \\
\hline 1.5 & $<1.25$ & 7.8 & 9.8 & 10.7 & 36.7 & 22.1 & . & - & . & $\ldots$ \\
\hline 16 & 1.8 & 5.11 & 10.6 & 9.0 & $45.1)$ & 18.5 & 2.04 & 3.37 & 2.16 & 3.03 \\
\hline 17 & $<1.25$ & (i.) & 13.0 & 11.4 & 59.8 & 20.83 & 3.28 & 4.11 & 4.26 & 4.69 \\
\hline 18 & $<1.25$ & +.0 & 13.8 & 11.2 & 28.1 & 20.6 & 2.70 & 2.983 & $3.7: 3$ & 3.34 \\
\hline 19 & $<5.7$ & (i.2) & 13.5 & 8.8 & 28.1 & 16.0 & 2.70 & - & 3.65 & - \\
\hline 20 & 1.7 & (j.) & 15.6 & 9.9 & 33.7 & 26.2 & & & & . \\
\hline Number & 20 & 20 & 20 & 20 & 20 & 19 & 17 & 16 & 17 & 16 \\
\hline
\end{tabular}

Mean $\pm \mathrm{sw} \quad 2.01 \pm 1.3 \quad 3.5 \pm 2.5 \quad 14.2 \pm 2.6 \quad 12.6 \pm 4.0 \quad 46.3 \pm 14.1 \quad 24.7 \pm 5.1 \quad 2.34 \pm 0.41 \quad 2.96 \pm 0.82 \quad 3.37 \pm 0.643 .57 \pm 0.84$ Paired t test

$$
\begin{aligned}
& t=5.90 \\
& P<0.01
\end{aligned}
$$$$
t=3.31
$$$$
t=7.31
$$$$
l<0.0(1) 1
$$

Thimits of sensitivity of the methed were $1.25 \mu$ mits/ml.

maximal values langed between 25 and $163 \mu \mathrm{units} / \mathrm{ml}$. No correlations were found between the height of the peak and level of TSI in the cord. The TSH disappeared very rapidly, falling to $50 \%$ of the peak values $2 \mathrm{hr}$ after birth and to $20 \%$ at the end of day 1 . By $48-72$ hr the values had returned to the levels found in cord serum. The TSH levels in the newborns, between 30 and 120 min after birth, fell in as an exponential decay. The calculated half-life ranged from 44 to 80 min. After $120 \mathrm{~min}$ the decay was much slower.

Data obtained from the paired maternal and cord sera samples are recorded in Table II. Maternal TSH levels ranged from $<1.25$ to $5.7 \mu$ units $/ \mathrm{ml}$ and were within the limits for normal nonpregnant women $(<1.25-7.0 \mu$ units/ml). The TSH levels in cord sera (2.1-10.7 $\mu$ units $/ \mathrm{ml}$ ) were higher than those found in normal children $5-12$ years of age $(<1.25-7.0 \mu$ units/ $\mathrm{ml})$. All cord values were within the range of sensitivity of the assay, whereas $10 \%$ of the sera samples found in normal adults and children are below the range of sensitivity. In each of the 20 cord samples, the TSH values were higher than those found in corresponding maternal sera. The difference was significant by the paired $t$ test $(t=5.90, P<0.01)$.
Thyroxine levels in maternal sera were significantly higher than those in the corresponding cord samples $(t$ $=5.90, P<0.01)$. This was not uniform for all indiviclual pairs, however, as some showed no difference or higher values in the cord sample.

The TBC: capacity measurements also indicated higher levels in maternal than in cord sample $(t=$ $7.31, P<0.001)$. This was true for all individual pairs, although some cord values overlapped the maternal range when each group was consiclered separately.

The $\mathrm{FT}_{4} \mathrm{~F}$ level was significantly lower in the maternal specimens than in the cord specimens $(t=4.66, P$ $<0.001)$, probably reflecting the higher TBG capacity. The mean cord level of $\mathrm{FT}_{4}$ was slightly higher than the mean maternal level, but it was not statistically different when examined by the paired $t$ test.

\section{Discussion}

Amounts of thyrotropic hormone in maternal and cord blood have been previously measured using a bioassay by Yamazaki and co-workers [29]. These authors found no differences between maternal and cord sera. Our data, along with those of Fisher et al. [8] and 
Robin et al. [26], demonstrate significantly higher cord levels for immunoreactive Istl. I Iowerer, in light of the recent identification of a human chorionic placental thyrotsopin (110.1) |13.1.1| and the demonstrattion that maternat and cord seta contain high levels of HC: ; [9], establishing that the immumereactive TSI measured in matemal and cord sera is IStl of pituitany origin becomes excecelingly important in interpreting these datit.

The anthuman pituitary ISII antiserum $|30|$ reacts very poorly with IIC:I: Hershman and Stames [1.1] noted that $100 \mu \mathrm{g}$ purified placental thyrotropin with a potency of 1.5 munits/mg on bioassay is cepuivalent to only 3 punits HTSI in the immunoalssay. Fisher et al. [9] reported that 2000 times more IIC:T than IITSH, by weight. wats reguired to produce equivalent displacement of radioiodinated IITSII from this particular antibody. In adlition, IIC:1 an measured by bioassaty was found to be near nompregnant levels in matcriat sera at $1 \mathrm{erm}|13|$. The possibility that this homone accounts for any of the measumable TSI in maternal or cord sera would thus seem remole.

Cross-reactivity of the antiserum [30) with He: and luteinizing homone (LIH) has been previously demonstrated [20]. After adsorbing the antiserum with large amounts of IIC(C) (20) Il), however, a very significant and specific dose-response curve for Hostl remained

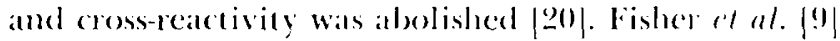
also noted that increasing the IIC:C; fiom 30 to 60 units decreases the percentiage of bound counts only 29. This observation was confirmed in our labonatory. The L.H Ig cross-peacts in the adsorbed ststem only to the extent that it is contaminated with TSII [20]: therefore, Lll and IICC: are not measured in this assity system.

Additional evidence of homogeneity of the assilyable ISH was demonstrated by the observation that sertum samples assiayed in cliflerent dilutions showed a parallel displacement comparable to that of the human pituitary standard curve. It would be reasonable to contclude that immunoreactive TSH in the maternal and newborn serum is in fact ISH of pituitary origin.

Whether the high levels of tsill in cord blood represent actual fetal levels of the hormone, and whether the stimulus responsible for the postnatal release of TSH is operative at term remain moot. Fisher and Odell $[8]$ were able to demonstrate similatly high levels of TSH in infants' scalp vein blood drawn prior to delivery. In a recent study $[11]$ we have investigated the thyroid function of 21 human fetuses (10-2) t weeks gestational age) and have shown that lsil was detected by radioimmunoassaly in significant amounts in nearly all instances. After 16 weeks gestation almost all Istl levels were comparable to those seen at term $(>4$ $\mu(11+1 \mathrm{ts} / \mathrm{ml})$.

It atso is unlikely that maternal TSH contributes to the high concentrations seen in cord sera. We were able to demonstrate that TSI concentrations in maternal sera are lower than those in cord samples (Table I), and that these differences atre present during most of fetal life [11]. These data are in accord with the obscrvation in animals that ISH is mable to cross the placentat in significant amounts [2-1]. It seems likely, then, that the rest measured at birth in cord samples are true reflections of the fetal enviromment and are only of tetal origin.

The explanations for the high fetal and cord TSH levels rematin speculative. The fetal hypothalamic-pimitary mechanism apparenty is not suppressible by free thyosine levels which are at the normal or ii)per normal range for older infants (Table II). Other explatuations require that some abnomal stimulus to ISI secretion in utero is present during most of fetal life.

The acute release of TSH observed in nomal newboms during the first minutes of life agrees with the observations of Fisher and Odell [8]. The phenomenon occured only in the newlootns and not in the mothers. serum TSH levels, determined in two mothers before delivers, and 1,2 , and $29 \mathrm{hr}$ after delivery, were constant. These findings are also in accord with those of Fisher and () bell [8].

The release of 'TSH during the early minutes of life occurs acutely and pobably without sustained hypersecretion during the subsequent 120 min. The halflife during this period $(1 /-80 \mathrm{~min})$ is comparable to that reported by odell ${ }^{\prime \prime}$ al. for the radioiodinated TSI (39-67 min) [19]. but it is slightly longer than hats been estimated for a pulse injection of HTSH (40 min) |l| The slower decas late after lon min and the persistance of cord levels at 72 hr of life could represent either a hypersecretion of ISH at this time or a slowing of the metabolic clearance rate cluring the period of fetal adjustment to extratuterine life.

The explatuation for the striking increase in TSH levels is obscure. The stress of delivery is not the stimulus for rSH secretion, as babies born by cesarean section present the sane TSII release phenomenon [8]. There is considerable evidence in animals that cold is a stimulus for TSH secretion $[\cdot 1,16$. In human adults, however, Odell at al. [29] were unable to show TSH release during cold exposure. Fisher and Oddie [7] have shown that prevention of neonatal cooling minimired the usual marked increase in protein-bound 
plasmat iodine (PBI) at the end of day l. Similarly, Fisher and Odell [8] demonstrated that cooling babies at $3 \mathrm{hr}$ of life produces a release of TSH, proving that exposure to a relatively cold enviromment is a TSH stimulus in the newborn. These authors, however, were unable to prevent the TSH peak from occurring by heating the babies just after birth. Possibly this was because a very short exposture to cold could not be avoided. The question of the role of cold in the acute release of TSH, then, remains unanswered, and a totally satisfactory explanation of the acute TSH release immediately after bigh awaits further study.

Other thyroid variables at birth have been assessed many times, and the literature oflers many contradictory observations. Some investigators have found higher mean PBI and butanol-extracted iodine values in maternal blood at delivery than in cord blood [3, 6, 10,18 , while others have found no difference [2, 9, 17, 22, 23, 25]. We have shown that matemal blood thyroxine levels are slightly, but significantly, higher than those in cord simples. This difference probably reflects the higher maternal I'BC:

Some investigators have reported higher cord values for $\mathrm{FI}_{4}[9,24,25]$; others have found values comparable 10 those of matcrnal serum [3]. Because $\mathrm{FT}_{\text {, }}$ is calculated as the product of total thyroxine and $\mathrm{FT}_{4} \mathrm{~F}$ in serum, the discrepancies in $\mathrm{FT}_{4}$ reported from different laboratories can partly be explained by different methods used to estimate thyroxine in serum. This fact does not allow any confidence in statements concerning maternal-fetal $\mathrm{FT}_{4}$ difference at term. In addition, we have recently shown that maternal $\mathrm{FT}_{4}$ levels are consistently higher than $\mathrm{FT}_{4}$ levels found in feuses of from 11 to 20 weeks gestation [11]. This observation would suggest that maternal-fetal $\mathrm{FT}_{4}$ difference at term has little meaning in terms of eatly fetal environment.

\section{Summat?}

Seren normal newborns monitored during the first 72 he of life had an acute, but unsustaincel, release of pituitary TSI in the early minutes of postnatal life followed by a step decline in serum levels at an initial rate companable to that reported for the half-life of the hermone. The slower decay rate noted after leo min and the persistance of hormone in blood at $72 \mathrm{hr}$ of life would inclicate that cither a hypersecretion of TSH occurs at this time or there is a slowing of the metabolic cleanance rate of TSH during the period of fetal adjustment to extrauterine life.

The TSII levels in 20 normal cord sera samples were consistently higher than paired maternal specimens.
Maternal levels were comparable to those of nonpregnant adult females; however, levels of TSH found in cord specimens were higher than those expected for nomal children. The specificity of the TSH assay would indicate that the immunoreactive TSH present in maternal and cord sera was of pituitary origin.

Maternal thyroxine levels were significantly greater than those found in cord serat, reflecting correspondingly higher levels of TBG in maternal specimens; $\mathrm{FT}_{4}$, however, was found to be not significantly different.

\section{Reforence's and Noles}

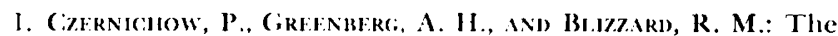
effect of dexamethasone (D) on TSH secretion rate (TSR) and the effect of 1$)$ and propylthiouracil (P'TU) on thyrotropin (1SH) levels. Clin. Res., 17:558 (1969).

2. Dinowsk, 'T. S., Jolnsion. S. Y., P'rick, W. C., Mickeivy,

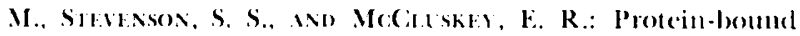
iodine in infants from bith to one year of age. Pediatrics. T: 2.40 (1951).

3. Dringk, P. H., Maldex, P., Van Din Schrifck, H. G., Brakiks, (... No dor Visschler, M.: Free thyroxine in maternal and cord blood. J. C:lin. Findocrinol., 26: 233 (1966).

4. Do.xcero, S. A.: Adenohypophyseal function in the guinea pig at low envirommental temperature. Fed. Proc., 19: 51 (19)(60).

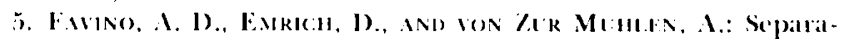
tion and gantitative determination of 131-1-triodothyonine and 1:31-1-thyoxine in human plasma by thin layer chromatography. Acta Eudocrinol., 5t: 362 (1967).

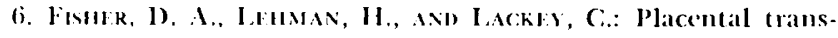
port of thyroxine. J. Clin. Endocrinol., 2t: 393 (1964).

7. Fisme, I). A., ANo Omone, 'I' H.: Neomatal thyroidal hyperactivity. Amer. J. Dis. (hild., 107: 574 (1964).

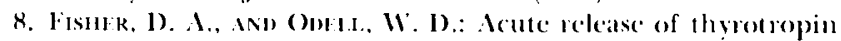
in the newbotn. J. C:lin. Insest.. fs: $1670(1969)$.

9. Fishle, 1). А., ODFl., W. 1)., IIOHF., (. J., AND GiARZA, R.: Thyorel function in the term fetus. Pediatrics, ft: 596 (1969).

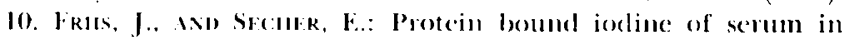
induced abotion and at delivery. Acta Endocrinol., 1s: 128 $(195: 5)$

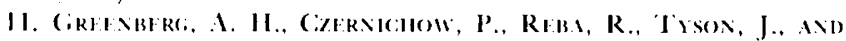

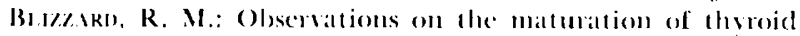
function in carly fetal life. J. Cilin. Invest., 19: 1790 (1970).

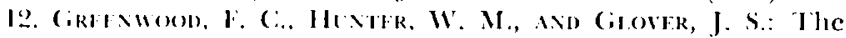
pepatation of $1: 1$ I labelled human growth hormone of high specific activity. Biochem. J., \%): $114(19963)$.

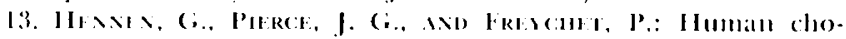
rionic therotopin: lurther chatacterization and study of its secretion during pregnancy. J. Clin. Endocrinol., 29: 581 (19)(9)

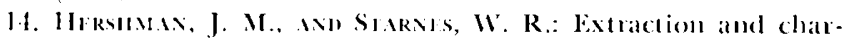
acteriation of a thyotropic matcrial from the human placonta. J. C:lin. Invest., fr: 923 (1!)6!).

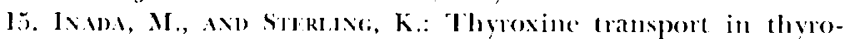
coxicosis and hypothyodidism. J. Clin. Invest., f6: 1.142 (1967).

16. Kxifis, K. M.: Neuroendocrine mechanisms influencing Ic:11 and Tsil secretion and the role in cold acclimation. Fed. Proc., 10: 15 (19)(0) 
17. Man, F. B., Pickering, D. F., Walker, J., ani Cooke, R. E.: Butanol-extractable iodine in the scrum of infants. Pediatrics, 9: 32 (1952).

18. Marks, J. F., Hamilin, M., and Zack, P.: Neonatal thyroid function. II. Free thyroxinc in infancy. J. Pediat., 68: 559 (1966).

19. Odel.t, W. D., Uticik, R. D., Witrer, J. F., and Condliffe, P. G.: Estimation of the secretion rate of thyrotropin in man. J. Clin. Invest., 46: 953 (1967).

20. Odeli, W. D., Vanstager, L., and Bates, R.: Radioimmunoassay of human thyrotropin. Atomic Energy Comm. Symp. Ser., 13: 185 (1968).

21. Onfli, W. 1)., Wilber, J. F., and Paut, W. E.: Radioimmunoassay of thyrotropin in human serum. J. Clin. Endocrinol., 25: 1179 (1965).

22. Oneit, W. D., Witble, J. F., and Uthere, R. D.: Stulies of thyrotropin physiology by means of radioimmunoassay. Recent Progr. Hormone Res., 23: 47 (1967).

23. Perky, R. E., Hodginan, J. E., and Stakr, P.: Maternal, cord and serial venous blood protein bound iodine, thyroid binding globulin, thyroid-binding albumin and prealbumin in premature infants. Pediatrics, 35: 759 (1965).

24. Petrerson, R. R., And Young, W. C.: The problem of placental permeability for thyrotropin, propylthiouracil and thyroxine in the guinca pig. Endocrinology, 50: 218 (1952).

25. Robisns, J., and Nroson, J. H.: Thyroxine binding by serum protein in pregnancy and the newborn. J. Clin. Invest., 37: 153 (1958).

26. Robin, N. I., Rretelt, S., Fang, V., and Selenkow, 11. A.:
Parameters of thyroid function in maternal and cord serum at term pregnancy. J. Clin. Endocrinol., 29: 1276 (1969).

27. Schlissler, G. C., and Plager, J. E.: Effect of preliminary purification of ${ }^{131} I$ thyroxine on the determination of free thyroxine in serum. J. Clin. Endocrinol., 27: 242 (1967).

28. Streri.ing, K., ANd Brinner, M. A.: Free thyroxine in human serum: Simplified measurement with the aid of magnesium precipitation. J. Clin. Invest., 45: 153 (1966).

29. Yamazaki, E., Noguchi, A., and St.ingerland, D. W.: Thyrotropin in the serum of mother and fetus. J. Clin. Endocrinol., 21: 1013 (1961).

30. Supplied by the National Institute of Arthritis and Metabolic Diseases, National Institutes of Health, Bethesda, Md.

31. Supplied by D. Bangham, World Health Organization, Mill Hill, Fngland.

32. 'Ietrasorb Kit, Abbott Laboratories, Chicago, Ill.

33. Abbott Laboratories.

34. We gratefully acknowledge the technical assistance of Mrs. Janice Owings and the secretarial assistance of Mrs. Mary Westervelt.

35. Supported by the Ministere des Afficires Ftrangeres Direction Gencrale des Relations Culturelles of France, the Medical Research Council of Canada, and Public Health Service Research (irant no. 110-01852.

36. Requests for reprints should be addressed to: R. M. Blizzard, M.l., Department of Pediatrics, Johns Hopkins Hospital, Baltimore, Mal. 2120:5 (CSA).

37. Accepted for publication Nay 12, 1970. 